\title{
An Economy of Abundance: From Scarcity to Human Potential in Organizational and University Life
}

\author{
Paul R. Yost \\ Seattle Pacific University \\ John R. Terrill \\ Stephen \& Laurel Brown Foundation \\ Helen H. Chung \\ Seattle Pacific University
}

\begin{abstract}
Emerging research and practice in workplace psychology is moving toward assessing people on a subset of competencies that divide the population into high and low potential employees. This article explores recent psychological research and business practices that have led to this state. Using the biblical story of the feeding of the 5,000 and Wesleyan theology around place, purpose, practice, and partnership, we illustrate how Christian thinkers and educators can acknowledge and transcend these findings and move from a scarcity to a perisseuma or abundance framework. Implications for organizational life in general and Christian higher education in particular are discussed.
\end{abstract}

Keywords: Scarcity, Abundance, Perisseúma, Wesleyan Theology, Christian Higher Education

\section{INTRODUCTION}

Over the last two decades, evidence suggests that a surprisingly small set of personal traits serve as strong predictors for how employees will perform in their current and future job roles (Schmidt \& Hunter, 2004). Furthermore, these traits can be easily measured with online or paper-and-pencil tests to predict employee performance across all job categories. The findings hold within the U.S. and abroad (Salgado et al., 2003). These results would not be particularly concerning if the traits could simply be developed, but research indicates that they are largely genetically determined and stable over a person's life (Bouchard \& Loehlin, 2001; Plomin \& Spinath, 2004; Roberts et al., 2006; Roberts \& DelVecchio, 2000; Schuerger \& Witt, 1989). For businesses, the implications are clear: some people have significantly more potential than others, and the natural conclusion is to hire, develop, and reward these "high potential" employees. While people's experience of common business practices may vary from this new reality, emerging practices in large organizations indicate that many have adopted this strategy (Church \& Rotolo, 2013; Silzer \& Church, 2009). In the words of George Orwell (1946) in Animal Farm, "Everyone is equal, but some are more equal than others." 
Christianity envisions a starkly different future - one in which everyone is valuable in God's eyes and can rise above what a personality or aptitude test might indicate is possible. The purpose of this paper is to chart a path forward that Christians in general, and the Christian academy in particular, can adopt to help society move beyond a "survival of the fittest" model of potential, rooted in scarcity, utility, and determinism. We propose a paradigm of perisseuma, a concept in the Greek New Testament signifying abundance, possibility, and superfluity (Bauer, 2000; Thayer, 1889). We further propose that a Christian understanding of potential should be built on four theological themes: place, practice, purpose, and partnership.

In the following discussion, we review emerging research in organizational psychology and trends in business practice that increasingly sort the working population into high potential (i.e., hipos) and low potential employees based on a subset of stable traits. We then introduce a theological perspective of potential that draws on the Johannine account of the feeding of the 5,000 and a Wesleyan theology of spiritual formation. Finally, implications for business organizations are considered, as well as the pivotal role that Christian Higher Education can play in advancing a Christian understanding of human and organizational flourishing.

\section{EMERGING TRENDS IN PSYCHOLOGY AND BUSINESS}

Emerging trends in psychology and business tend to reinforce a paradigm of scarcity based on individuals' capabilities to perform for the benefit or profitability of workplace organizations. We begin by reviewing these findings and their natural conclusions.

\section{New Findings in Psychology}

From as early as 700 C.E. in China, organizations have been interested in developing systems to select the best people for particular jobs (Ployhart et al., 2006). In the early twentieth century, scientific approaches to studying employee selection were introduced, which have been codified in state and federal laws. Since the Uniform Guidelines for Employment Practices were issued in 1978, federal law has specified that organizations should select employees on the specific knowledge, skills and abilities (KSAs) required to perform the job (Code of Federal Regulations, 2011). The challenge that organizations face, especially large organizations operating in progressively volatile economic environments, is that they have a wide variety of ever-changing roles that are difficult to fill. Organizations first responded by clumping similar jobs into job families, thereby allowing the use of a single assessment battery to select employees for an appropriate group of positions (e.g., all sales representatives independent of products sold). Yet, organizations and researchers have now gone further in an effort to mitigate risk, looking for relatively stable personality characteristics that predict success across multiple jobs.

As one might suspect, they found them. Advances in research methods and statistics allowed researchers to detect a few traits predictive of job performance across job families and even across organizations (Ryan \& Tippins, 2004). With this new research, organizations could be much more efficient in their hiring practices; that is, in the same way that colleges and universities rely on SAT or ACT scores to predict student performance across colleges and majors, organizations could increasingly rely on standardized assessments offered by several research-based consulting firms to predict performance across a wide variety of jobs.

As a result, organizations have moved from stable traits for selection purposes only to a suite of stable employee competencies that can apply more broadly (Campion et al., 2011). Competencies such as decision making, responsibility, and people skills have been demonstrated to predict success across all jobs, thereby heightening the value of such traits over other attributes. The implications have only recently worked their way into the popular press. For example, the Atlantic Monthly recently ran an article entitled "The war on stupid people: American society increasingly mistakes intelligence for human worth," highlighting that selection firms such as CEB assess 40 million job applicants per year on intelligence and personality traits alone (Freedman, 2016; Salgado, 1997; Schmidt \& Hunter, 2004). 
Today, most organizations have adopted a systematic framework for selecting employees using structured interviews, IQ tests, and personality tests to identify and hire the best candidates for a job. The development of new statistical techniques has enabled researchers to pool findings across organizations and jobs to identify a subset of personal characteristics predictive of performance across all jobs. Three characteristics have emerged as particularly important: general cognitive ability, conscientiousness, and emotional stability. Research suggests that cognitive ability predicts up to $36 \%$ of the variance in people's job performance (Salgado et al., 2003; Schmidt \& Hunter, 2004), conscientiousness predicts 5\% or more across all jobs; and emotional stability predicts individual and team performance across all jobs (Dudley et al. 2006; Salgado, 1997). Moreover, emotional stability and other personal characteristics, such as positive and negative affect can predict individuals' satisfaction with their jobs (up to 45 percent of the variance in job satisfaction; Bouchard \& Loehlin, 2001).

These findings are not particularly disturbing if people can change their personality characteristics over time. However, as noted earlier, these traits are largely genetically determined and stable. Many of today's larger corporations have embraced these findings. Pragmatically, they ask, if a few simplyadministered tests can predict employees who will be the best performers and most satisfied, why not use them? According to this perspective, an abundance mindset that values all employees sounds noble, but is ultimately impractical for thriving in a highly competitive environment. Is there an alternative?

\section{TOWARD A BIBLICAL AND THEOLOGICAL BASIS FOR ABUNDANCE}

\section{Feeding the 5,000 as a Lesson in Abundance}

John's account of the feeding of the 5,000 (John 6:1-15) - the only miracle recorded by all four Gospels (Guthrie, 1994) - highlights the disciples' struggle to see potential where none seemingly exists. This particular biblical account featuring one child, one small meal, and one hesitant disciple reflects the transformative power of perisseuma, a concept in the Greek New Testament that signifies possibility, even superfluity (Bauer, 2000; Thayer, 1889).

The story of the loaves and fishes can be seen as a contrast of limitations and fear with abundance and faith. As the narrative describes, there was not nearly enough food to feed the more than 5,000 people who had gathered to hear Jesus teach. And, if the situation was not already bleak, Jesus implicated the disciples by involving them in the task of provision. Surveying the large crowd, Jesus said to Philip, "'Where are we to buy bread for these people to eat?" (John 6:5, NRSV). Bread (or artos in Greek), a staple food in the Near Eastern world, is often used interchangeably in the Bible with a meal, sustenance, or life itself (Cook, 1993; Reed, 2000). By asking Philip about bread, Jesus seemed intent on providing the crowd a hearty meal. At another level, Jesus was issuing an important lesson for his closest followers: Where you see scarcity, God sees abundance.

And so, in the lives of the disciples, we see two possible responses to Jesus' challenge. Philip's answer is pragmatic. "Six months' wages would not buy enough bread for each of them to get a little." (John 6:7, NRSV). The focus on prohibitive cost reflects Philip's lack of understanding (Guthrie, 1994; Scott, 2003). Andrew's perspective, on the other hand, is tentatively more hopeful. "'There is a boy here who has five barley loaves and two fish. But what are they among so many people?"' (John 6:9, NRSV). Moving a half-step closer to envisioning abundance, Andrew perceives a possible resource in the boy's fish and barley loaves, the kind of bread eaten primarily by the poor (Stein, 1989; Vawter, 1968). Andrew's faith is tentative at best, yet Jesus works with limitations, in this case both material and spiritual.

But the story does not end with simple provision. Jesus tells his disciples, "Gather up the fragments left over, so that nothing may be lost" (John 6:12, NRSV). The Greek word for "leftover" is perisseúsanta, meaning overflowing, in excess. Here, even the "leftovers" are significant. God's provision is the antithesis of parsimony; it has superfluity not only in what is initially given but also in what remains. 


\section{A Wesleyan Perspective of Human Potential}

Theological models provide an additional lens through which one can more broadly examine the kind of possibility that Jesus demonstrated in the feeding of the 5,000. Although Wesley did not teach directly on human potential, he wrote and spoke extensively on the nature and process of human salvation with a pragmatic emphasis to help Christ's followers respond continuously to God's ongoing grace. More specifically, Wesley's writings captured the spirit of abundance that emerges through people's place in God's plan, the process (or practice) of growth and sanctification in relationship with God, the purpose of humankind in God's redemptive work, and the partnership toward wholeness and glorification that God initiates and sustains.

Wesley noted that all people have a place; they are stewards of what God "hath entrusted ... with our souls, our bodies, our goods, and whatever other talents we have received" (Wesley, 1872). People are to be faithful stewards with these gifts in God's service. Furthermore, Wesley understood salvation as a process or practice that plays out over time. Wesley's understanding relied on early Eastern theology and later Anglican thought that highlighted a therapeutic and healing-oriented model of human restoration, which stood in contrast to the traditional Protestant emphasis on a juridical understanding of salvation (Maddox, 1994). In Wesley's view, salvation was not just a particular moment of justification, but rather a process of sanctification over a lifetime that continues to consummation (glory) in the life to come (Maddox, 1994).

In Wesley's reading of Scripture, a theological understanding of God's creation points toward human growth and sanctification, transcending a purely individualistic and deterministic perspective of potential. Like other Christian traditions, Wesley acknowledged the wholesale impact of sin, describing rebellion as severed relationship with God, other human beings, animals, and even oneself (Maddox, 1994); however, he also saw the potential of human beings to find life, self-acceptance, and deep purpose once relationship to God, neighbor, and the rest of creation was restored (Maddox, 1994). In his historical context, where the poor were often devalued, Wesley taught that people in God's kingdom were more than the utility society often assigned to them. They had value, meaning, and ultimate worth because of God's image sewn into them.

As noted, Wesley's practical discipleship centered on a sanctification process that unfolds progressively in a lifetime of holiness. This idea is captured well by the concept of partnership (i.e., participation with God), a process by which human beings partake in the divine nature by increasingly reflecting the image of God as first actor in their lives now and in the life to come (Castelo \& Stone, 2012; 2 Peter 1:4).

"Salvation, then, is not to be conceived only in the negative sense-saved from sin-but
in a positive sense as well: saved for a life of holiness. Such a view envisions salvation as
sanctification. Salvation is a participatory journey of divinization in which we as
individuals are changed and thereby empowered as agents of change on the earth"
(Castelo \& Stone, 2012, p.18).

In this way, sanctification can be conceptualized as a sacred dance between God and humanity that depends on both parties but is initiated by God. At the heart of Wesley's practical framework is an understanding of sanctifying grace that requires divine and human cooperation in the ongoing salvific process. In other words, grace is co-operant; we must effectuate it, yet it is also entirely dependent on the salvific work of God (Collins, 2007). Humanity cannot attain holy lives independent of God's grace, yet God will not complete holiness in humanity apart from individuals' faithful participation (Maddox, 1994).

Thus, Wesley's understanding of salvation is not static but expansionistic and a gift of divine grace. The purpose of sanctification not only demands inner lives of holiness, but also an alignment of integrity and well-being in our outward, practical lives (Maddox, 1994). When seen in this holistic light, the experience of sanctification serves to reconstitute every relationship in our lives and "opens up a momentby-moment process of growth in grace as we practice holy living in the fruits of the Holy Spirit" (Strong, 2012, p. 68). 


\section{PERISSEUMA: A CHRISTIAN PARADIGM OF POTENTIAL}

Building on the concept of perisseúma and a Wesleyan approach to potential, Christian scholars and practitioners can both acknowledge and embrace the latest psychological research, yet transcend the findings to chart a different way forward. Toward this end, we propose the perisseuma paradigm, which invites organizational members and educators to value and model four principles that lead to greater human flourishing:

- Place. A Christian perspective of humanity starts with a mutuality-oriented view. The whole is greater than the sum of the parts. Everyone has a place - a unique role to play that is critical to the larger picture. Differences in individuals and in educational institutions can complement and enhance one another.

- Practice. A Christian perspective of humanity argues that people develop over time. How people recognize and engage their abilities, talents, and experiences is what is most important. To increasingly mirror the Imago Dei, people are called to adopt practices such as love, joy, peace, gratitude, and forgiveness in their relationships. In our sacred and participatory dance with our creator, people are called to develop their character by walking closely with God and with others.

- Purpose. A Christian worldview starts by defining each person as God-breathed-loved by God and created for God's purposes. A person's value is not defined functionally by what $\mathrm{s} / \mathrm{he}$ is able to do or contribute but rather by who they are as a person-God's beloved.

- Partnership. People and the organizations they serve are not the first actors but are recipients of God's grace. People are called to partner with a loving God, who is with them and for them, and who uses their weaknesses and strengths to bring reconciliation and restoration to a world in need. Although our identity is not rooted in performance, each person, community, and institution is invited to play a vital role in God's redeeming work in the world.

Together, these four principles transform a discussion of scarcity (who is "best") into a discussion of abundance and mutuality (what role and purpose do we play individually and together). When considering the four dimensions, there is some natural commonality. For example, one cannot discuss the importance of a person's unique place in the world without discussing purpose as well (e.g., service to others). At the same time, we propose that none of the four dimensions can be omitted; the constructs are both unique and interdependent. The remainder of this paper explores these factors at individual and educational levels, offering specific implications for faculty and administrators serving in Christian higher education.

\section{A Tale of Two Paradigms}

Adopting a scarcity or abundance model has direct implications for how individuals and organizations think about themselves and serve their constituencies (see Table 1). A stark contrast between the two, of course, oversimplifies what is really a continuum of the many perspectives people bring to their work and lives. Nonetheless, this contrast is important to call out because it reflects a dominant narrative that affects one's understanding of human potential and institutional purpose. As people tend to lead with one paradigm or the other, defining the contrast here illuminates how Christian theology confronts the basic assumptions that often remain unchallenged in psychology, business, and higher education today. 
TABLE 1

A TALE OF TWO PARADIGMS

\begin{tabular}{|c|c|c|c|}
\hline & & $\begin{array}{c}\text { Scarcity } \\
\text { Metaphor: Survival of the } \\
\text { Fittest }\end{array}$ & $\begin{array}{c}\text { Abundance } \\
\text { Metaphor: Fit to } \text { Thrive }\end{array}$ \\
\hline \multirow{2}{*}{$\begin{array}{l}\text { Potential as } \\
\text { Place: Every } \\
\text { person and } \\
\text { organization has } \\
\text { a unique, special, } \\
\text { and } \\
\text { complementary } \\
\text { role to play in } \\
\text { community and } \\
\text { in society. }\end{array}$} & Individual & $\begin{array}{l}\text { Some individuals possess a } \\
\text { subset of traits (e.g., IQ, } \\
\text { conscientiousness, emotional } \\
\text { stability) that are largely } \\
\text { genetically based and } \\
\text { predictive of positive work } \\
\text { performance across a wide } \\
\text { range of jobs. These "high } \\
\text { potential" individuals are } \\
\text { deemed more valuable to } \\
\text { organizations and society. The } \\
\text { goal is to identify, select, and } \\
\text { reward high potential } \\
\text { employees to maximize } \\
\text { organizational performance. }\end{array}$ & $\begin{array}{l}\text { Everyone plays a valuable role } \\
\text { in God's kingdom, possessing } \\
\text { a unique constellation of gifts, } \\
\text { skills, and experiences. The } \\
\text { goal is to find the places where } \\
\text { these gifts can be used to } \\
\text { complement and enhance other } \\
\text { people, organizations, and } \\
\text { society as a whole. Rather } \\
\text { than identifying a few people } \\
\text { with special traits, a person's } \\
\text { unique combination of traits, } \\
\text { skills, and experiences are } \\
\text { matched to specific needs. }\end{array}$ \\
\hline & Organizational & $\begin{array}{l}\text { Some organizations are more } \\
\text { valuable than others. The } \\
\text { strong ones will survive, and } \\
\text { the weak ones will die. The } \\
\text { goal is to maximize } \\
\text { organizational value and } \\
\text { efficiency and pursue } \\
\text { identifiable target markets to } \\
\text { ensure profitability and long- } \\
\text { term success. }\end{array}$ & $\begin{array}{l}\text { Organizations need to work } \\
\text { hard and build efficiencies to } \\
\text { remain competitive, but they } \\
\text { also need to pursue the unique } \\
\text { role they are called to play. } \\
\text { Different types of } \\
\text { organizations serve important } \\
\text { and complementary roles in } \\
\text { creating a better world. }\end{array}$ \\
\hline \multirow{2}{*}{$\begin{array}{l}\text { Potential as } \\
\text { Practice: } \\
\text { Potential is } \\
\text { dynamic; people } \\
\text { and } \\
\text { organizations are } \\
\text { growing and } \\
\text { developing in } \\
\text { serving God and } \\
\text { others. }\end{array}$} & Individual & $\begin{array}{l}\text { Individuals have little control } \\
\text { over their traits and/or the } \\
\text { environment, and are unlikely } \\
\text { to change over time. "What } \\
\text { you see is what you get." The } \\
\text { goal of organizations is to hire } \\
\text { and invest in the people who } \\
\text { have characteristics that predict } \\
\text { adaptability and growth (e.g., } \\
\text { IQ, conscientiousness). }\end{array}$ & $\begin{array}{l}\text { Every person can adopt } \\
\text { practices to discover their } \\
\text { unique strengths. People and } \\
\text { organizations are capable of } \\
\text { change and growth. The goal is } \\
\text { not simply to maximize utility } \\
\text { but to engage in practices (e.g., } \\
\text { love, gratitude, and } \\
\text { forgiveness) that lead to } \\
\text { greater service and wholeness. }\end{array}$ \\
\hline & Organizational & $\begin{array}{l}\text { Organizational strengths and } \\
\text { weaknesses are relatively stable } \\
\text { and will be adaptive only as } \\
\text { long as they match the } \\
\text { environment around them. If } \\
\text { context changes, the firm is } \\
\text { threatened. }\end{array}$ & $\begin{array}{l}\text { Organizations, as dynamic } \\
\text { systems, can learn, adapt, and } \\
\text { develop to help society } \\
\text { flourish. Organizations can } \\
\text { leverage their unique strengths } \\
\text { within a competitive } \\
\text { environment. }\end{array}$ \\
\hline
\end{tabular}




\begin{tabular}{|c|c|c|c|}
\hline & & $\begin{array}{c}\text { Scarcity } \\
\text { Metaphor: Survival of the } \\
\text { Fittest }\end{array}$ & $\begin{array}{c}\text { Abundance } \\
\text { Metaphor: Fit to Thrive }\end{array}$ \\
\hline \multirow[t]{2}{*}{$\begin{array}{l}\text { Potential as } \\
\text { Purpose: A } \\
\text { person's value is } \\
\text { not defined } \\
\text { functionally by } \\
\text { what s/he does or } \\
\text { feels, but by who } \\
\text { they are as a } \\
\text { human being } \\
\text { created in God's } \\
\text { image. }\end{array}$} & Individual & $\begin{array}{l}\text { The purpose and value of the } \\
\text { individual is to maximize } \\
\text { efficiency, utility, } \\
\text { organizational gain, and the } \\
\text { survival of the human species. } \\
\text { Individual purpose is about } \\
\text { getting one's fair share, not } \\
\text { necessarily about serving the } \\
\text { greater whole. }\end{array}$ & $\begin{array}{l}\text { The ultimate purpose and value } \\
\text { of people is to love God and } \\
\text { others, and join God in } \\
\text { bringing restoration and } \\
\text { wholeness to the world. Utility } \\
\text { and efficiency may ensure } \\
\text { viability and relevance but } \\
\text { these are the means to the end } \\
\text { goal of love and service. }\end{array}$ \\
\hline & Organizational & $\begin{array}{l}\text { The purpose of organizational } \\
\text { life is to maximize return (often } \\
\text { in the form of profits or donor } \\
\text { dollars), rather than to serve } \\
\text { other key internal and external } \\
\text { stakeholders. }\end{array}$ & $\begin{array}{l}\text { Generating revenue and profits } \\
\text { are important, but only as a } \\
\text { means to another end - loving } \\
\text { God and others through acts of } \\
\text { service so that communities } \\
\text { might fully flourish. }\end{array}$ \\
\hline \multirow{2}{*}{$\begin{array}{l}\text { Potential as } \\
\text { Partnership: } \\
\text { People and the } \\
\text { organizations } \\
\text { they serve are } \\
\text { not the first } \\
\text { actors, but are } \\
\text { recipients of } \\
\text { divine grace. } \\
\text { God uses } \\
\text { people's } \\
\text { strengths and } \\
\text { weaknesses, } \\
\text { alike. }\end{array}$} & Individual & $\begin{array}{l}\text { Individuals are valued because } \\
\text { of their capacity to perform and } \\
\text { deliver results. Strengths are } \\
\text { celebrated and weaknesses are } \\
\text { often ignored, even punished. }\end{array}$ & $\begin{array}{l}\text { Ultimately, we are part of } \\
\text { God's story-living our lives in } \\
\text { grateful response to God's } \\
\text { unconditional love. God can } \\
\text { use a person's strengths and } \\
\text { weaknesses to bring } \\
\text { redemption and hope. }\end{array}$ \\
\hline & Organizational & $\begin{array}{l}\text { An organization's ultimate } \\
\text { purpose is to deliver results and } \\
\text { to ensure its survival at all } \\
\text { costs. There is no place for } \\
\text { authenticity, vulnerability or } \\
\text { confession in organizational } \\
\text { life. }\end{array}$ & $\begin{array}{l}\text { Institutions and organizations } \\
\text { are ultimately part of God's } \\
\text { emerging story. They can be } \\
\text { used by God in all of their } \\
\text { imperfections to help redeem a } \\
\text { fallen world. }\end{array}$ \\
\hline
\end{tabular}

\section{Potential as Place}

A scarcity paradigm presumes that some people are stronger and more valuable than others, which results in the organizational pyramid imagery and "survival of the fittest" narrative that dominate many organizations today. In a perisseúma paradigm, however, place sets free the liberating concepts of mutuality and complementarity - that every person has something unique to offer the broader community. Consequently, the goal is instead to find the right "fit" for individuals, the place where each person's talents match what is required to perform the job well (Kristoff-Brown, Zimmerman, \& Johnson, 2005). For example, building a plane takes engineers to design it, mechanics to build it, and marketers to sell it. Different trait and skill profiles are required for each of these tasks. Only in shared responsibility can the plane be successfully constructed.

In contrast to a pyramid image of organizational life where the best and strongest move up, the Christian narrative uses the image of the body where every member is needed (1 Cor. 12:14-26; Rom. 12:4-8); potential is most fully realized when individuals are able to find their place within their organizations and communities. A Christian understanding of place considers how the constellation of an individual's gifts, abilities, experiences, and even limitations serve the whole. Of course, the model presented in Scripture is for the church; one should ask, how does the analogy apply to society? A rich theological history on this issue that draws on Luther, Calvin, and other Reformers in Protestant circles 
and papal and Catholic social teaching argues that this model should serve as a template for framing broader organizational life. Religious roles are not granted preferential treatment in God's kingdom. Instead, everyone has an important role to play in bringing peace and restoration; whatever a person does, as long as the work is good and worthy and honors God, it delivers lasting value to society (Schuurmann, 2004).

Applying a complementary rather than a competitive lens to organizations moves beyond the simplistic question: "Does this person have potential?" to the more important and nuanced question, "potential for what?" (Yost \& Chang, 2009). Group, organizational, and societal potential cannot be considered in isolation. Collective potential is dependent on all of the parts because they are complementary, interdependent, and emergent. The study of teams within organizations confirms that a diversity of knowledge and skills can lead to emergent properties that make the whole greater than the sum of its parts, provided that the right practices are in place (as discussed in the next section; Hertel, 2011). Focusing narrowly on people, or worse, a few attributes held by a few individuals is competitively dangerous for organizations trying to operate in complex, dynamic environments, because their ability to adapt to new challenges will be compromised (Schneider, 1987; Uhl-Bien, Marion, \& McKelvey, 2007).

At the societal level, the world needs physicists, police officers, customer service workers, executives, and even politicians who love neighbor and community. Rather than looking for attributes that predict success across all jobs and for people with these limited attributes (a scarcity mindset), an abundance mindset is committed to building a society where individuals find their "fit." For example, extraversion might be one of the more important traits for salespeople (Barrick \& Mount, 1991), while cognitive ability might emerge as a critical skill for managers and engineers (Bertua, Anderson, \& Salgado, 2005). A theologically informed perspective of place moves organizations beyond a simple sorting of employees into levels of "potential" to a broader perspective of creating a body (or ecosystem) where people strive to help one another find their niches in ways that expand potential (Cable \& Edwards, 2004).

At the organizational level, companies similarly need to find their niche within the broader marketplace. In his book Good to Great, Jim Collins (2001) encourages organizations to define the one best thing they can do well (the Hedgehog Principle) based on three dimensions: (1) what are they naturally good at? (2) where is their passion? (3) and what drives their economic (i.e., resource) engine? In other words, organizations need to determine how their strengths and passion can be combined in ways that create value for which others are willing to pay or offer something of value in exchange. Rather than primarily framing their existence in terms of competition, organizations can alternatively shape their mission and strategy around the unique market offerings they distinctively deliver (Porter, 1979).

\section{Potential as Practice}

A scarcity paradigm is built on the premise that people have little control over their own traits and abilities and how to employ their traits to accomplish higher order goals. In contrast, a Christian perspective rooted in theological ideas of spiritual transformation, sanctification, and holiness shifts the emphasis toward how inherent abilities can be uniquely leveraged for personal growth and service opportunities. Every person and organization can learn and adopt practices to discover their unique strengths, employ strategies to compensate for shortcomings, and make use of the results of self-discovery to serve others and bring greater flourishing to the world. Intelligence serves as a good example.

Research suggests that intelligence can be divided into two dimensions: fluid intelligence (abstract thinking and problem solving), which is mostly genetically determined, and crystalized intelligence (experience, memory, knowledge accumulation on how to manage a problem), which can be developed via education and experience ( $\mathrm{Li}$ et al., 2013). People may be born with a certain level of fluid intelligence, but they can also learn critical thinking skills and practices that expand their reasoning capacity. Although fluid intelligence decreases over time, crystalized intelligence can increase over time, resulting in stable or even improved performance as a person ages ( $\mathrm{Ng} \&$ Feldman, 2013). For example, expert performance in fields like medicine, music, sports, and chess does not come naturally but requires 
active, deliberate practice - at least 10,000 hours over a 10-year period (Ericsson, Charness, \& Hoffman, 2006; Ericsson \& Ward, 2007).

Indeed, the idea that practice is critical over and above talent continues to find support in research. Duckworth's (2016) book, Grit, highlights what she calls paragons of grit, or people who have demonstrated both passion and perseverance for their long-term goals. Across their stories, the common denominator is not raw talent but persistence, the will to find a way to pursue goals paired with followthrough, even in the midst of challenges. People with a fixed mindset, the belief that their capabilities are set, tend to avoid challenges that threaten their self-image and are less resilient after failures, compared to people with a growth mindset, who are more likely to look for challenges, learn from failures, and be persistent (Dweck, 1986).

People can also develop strategies about how best to deploy their skills. Emerging research suggests that people regularly engage in "job crafting," tailoring jobs in ways that fit their skillsets (Wrzesniewski \& Dutton, 2001). A scholar, for instance, may have strong writing skills but weak statistical skills so s/he partners with another scholar with the opposite profile. Gallup researchers suggest several strategies to manage around one's weaknesses (Buckingham \& Clifton, 2001). For instance, individuals weak in conscientiousness can seek employment where it will be less of an issue (e.g., choosing a profession where being absent-minded is considered endearing), find ways to get "good enough," or build systems to compensate (e.g., using a calendar to keep track of assignments and dates).

Research also suggests that spirituality and religion can help people redirect their inborn traits. For example, after a conversion experience, people's temperaments and personalities do not change (e.g., introverts remain introverts, people who tend to focus on problems still tend to focus on problems); however, their goals, values, emotions, and behaviors often exhibit profound changes - in other words, temperaments stay the same but are focused in new life directions (Paloutzian, Richardson, \& Rambo, 1999). Furthermore, spirituality increases self-control and people's ability to regulate their behavior (McCullough \& Willoughby, 2009). For example, Pargament, Koenig, and Tarakeshwar (2001) found that positive religious coping strategies (e.g., viewing God as a partner in overcoming difficulties) can have a strong positive effect on stress reduction, health, and even mortality rates above and beyond the other coping strategies. Moreover, Christian practices such as gratefulness, prayer, using one's talents, forgiveness, and active participation in a faith community have long-term positive effects on health and well-being (Bade \& Cook, 2008; Fredrickson, Cohn, \& Coffey, 2008; Hill \& Pargament, 2008; Pargament, 2008; Worthington, 2008). At the group level, people can learn and employ behaviors such as giving and receiving feedback or taking another's perspective, thereby significantly improving team effectiveness (Ohland et al., 2012; Salas, Shuffler, \& Thayer, 2014). This sampling of research demonstrates the capacity for human beings to employ practices and experiences to leverage traits for long-term good and service.

\section{Potential as Purpose}

Potential, in a scarcity paradigm, is most commonly defined functionally as the ability to contribute to the bottom-line. This assumption is reflected in many of today's management theories and influences the MBA training curriculum (Ghoshal, 2005; Wong, Baker, \& Franz, 2015). Under this system, people are valued because of their utility; service and stewardship are important because they lead to more profitable businesses as opposed to serving society where profit is a means to service and stewardship (Van Duzer, 2010).

Purpose and meaning at work has emerged as an increasingly common topic in management research (Park, 2012). The hunger for meaning in the workplace - what some have labeled "the purpose economy" (different than the agrarian, manufacturing, and information economies that preceded it) - has recently received increasing attention as people's universal quest to enjoy greater meaning through engaging work, service to others, and opportunities to build deeper community has intensified (Hurst, 2014). A Christian worldview that legitimizes and harnesses purpose-driven work is particularly attractive in an economy increasingly made up of people who say they lack purposefulness. For example, research suggests that 40 percent of Americans report that they do not have a satisfying purpose in life (Smith, 2013). Christianity 
directly addresses this fundamental underlying question: what is the ultimate aim of work and of organizations? Utility and profitability are important, but they are a means to an end (Van Duzer et al., 2007). The purpose of work viewed through a Christian abundance lens is multidimensional: to organize people in ways that provide value to customers and other crucial stakeholders, to provide a place where people can use their God-given gifts, and to partner with God as co-creators in bringing redemption to a broken world (2 Corinthians 5:18-21; Romans 8:22; Diddams \& Daniels, 2013). A Christian worldview challenges organizations to live into an abundance mindset where the ultimate purpose is to love God and others (Matthew 22:36-40).

In an abundance paradigm, the organizational mission moves beyond just profit as the end goal to consider the broader societal contribution (Ghoshal, 2005; Pearce \& David, 1987). For Christians, this might mean working within traditional organizations that offer a good product or service that meets a legitimate need in the world, or choosing to work for organizations that more explicitly address matters of justice, shalom, and restoration. In an abundance-oriented workplace, the lines are not drawn narrowly but expansively. Many organizations can contribute to a better world; the responsibility falls on individuals to ensure that they are indeed serving the common welfare of society.

Within some business sectors, the pendulum may be swinging in the direction of this more expansionistic outlook, and scholars have increasingly noted that there are constituencies beyond just shareholders that warrant careful attention. Gates's (2008) "creative capitalism," Mackey and Sisodia's (2013) "conscious capitalism," and Porter and Kramer's (2011) "shared value" are several examples highlighting reform movements. In this way, the purpose of business is to create products and services that lead to greater societal flourishing as well as to craft meaningful work that honors employees' unique strengths, interests, and God-given dignity (Van Duzer, 2010). Organizations that pay attention to what they are building internally contribute meaningfully to people, who in turn thrive and work toward greater human flourishing. More of this kind of expansionistic outlook is needed across all types of organizations.

\section{Potential as Partnership}

Partnership refers to God's divine act where humans are not the first actors but are acted upon by a loving God, and invited to participate in God's ongoing creation and redemption. God's grace, expressed through Christ's life, death, and resurrection, reconciles sin and redeems humanity and human potential. The Person-God partnership starts and finishes with identity in Christ (Col. 2:6-7), with the individual and organizations intentionally seeking to serve Christ's purposes. Ultimately, a Christian understanding proposes that people's potential is not defined by what they do, but by whose they are (Guinness 1998). As Wright (2008) notes, God's creation was a magnificent act of love, affirming the intrinsic value of all that was created.

A theologically-informed perspective of human potential invites people to surrender weaknesses and frailties, trusting God to redeem and use them for the betterment of self and others (Romans 8:31-39). Christians operate with the countercultural belief that if they metaphorically bring the meager basket of five loaves and two fishes, Jesus can transform it to feed a multitude. The idea that God uses our shortcomings and even our brokenness is at the heart of the partnership framework, overturning how we tend to think about potential.

In business, theorists have written about the importance of stewardship and servant leadership, but they often wrestle to apply this advice to a world where individuals and organizations operate in ways to maximize self-interests (Davis, Schoorman, \& Donaldson, 1997; Ghoshal, 2005). "Greed is good" might be caricatured in movies like Wall Street, but it stubbornly remains a basic tenet in many economic practices. Amidst injustice, Christianity transcends this inherent tension by acknowledging that while evil does exist, God uses the authentic and vulnerable of the world to redeem creation. For example, attributes like gratitude are infectious and promote prosocial behavior in others (Grant \& Gino, 2010), and organizations that support justice and have a strong ethical culture are more likely to flourish over time (Spreitzer \& Cameron, 2012). The point is that the gospel fundamentally redefines success: Christians in all of their weakness and vulnerability are not called to mere material gain but to righteousness, obedience, authenticity, and service that leads to the flourishing of others (Luke 12:16-21). 


\section{WHAT THIS MEANS FOR CHRISTIAN HIGHER EDUCATION}

The story of God's redemptive purposes in the world through Christ provides hope in a world where injustice often appears to win the day. Christians can have the courage to do the right thing independent of the consequences, knowing that God is with them in the present and has dominion in the unknown future. The implications and call to action are particularly significant for Christian faculty and administrators who are developing the next generation of leaders: How can the academy promote a new metaphor that moves away from a model of fixed potential and scarcity to one that expansively defines the potential of individuals and organizations? How can Christian faculty model an abundance mindset in their research and teaching to nurture the next generation to be a people of hope (Moltmann, 1967, 2004)?

\section{Perisseúma in Christian Higher Education}

While Christian higher education is challenged today to remain competitive and profitable in the larger educational arena, its differentiated mission (and advantage) resides in the opportunity to develop the whole student and restore in others the image of God by preparing young people to profoundly influence the places where they work and live. To do so, faculty at Christian educational institutions play a prophetic role in their teaching, scholarship, and service to the university.

We highlight the faculty role within the university for two reasons. First, faculty hold a central boundary-spanning place within Christian higher education: working at the institutional level with the administration and staff; working with students through their teaching and advising; and working externally through their scholarship and within their professional/academic guilds. Thus, broad implications can be addressed by discussing how faculty can build perisseúma across these roles. Second, faculty as a whole can be a rather critical, even skeptical group. Academic training is designed to build and reward critical thinking and analysis. Maintaining a perisseúma approach does not necessarily come instinctively to this or any other group trained to critique. If Christian faculty will own a perisseúma perspective, others will take notice.

Therefore, in the final section of this paper, we examine how the four elements of perisseúma-place, practice, purpose, and partnership — can reshape how faculty members engage in teaching, scholarship, and service within their institutions (see Table 2).

TABLE 2

\section{IMPLICATIONS FOR FACULTY IN CHRISTIAN HIGHER EDUCATION}

\begin{tabular}{|c|c|c|}
\hline & In Teaching and Scholarship & In Service to the Institution \\
\hline $\begin{array}{l}\text { Potential as } \\
\text { Place: Every } \\
\text { person and } \\
\text { organization has } \\
\text { a unique, } \\
\text { special, and } \\
\text { complementary } \\
\text { role to play in } \\
\text { community and } \\
\text { in society. }\end{array}$ & $\begin{array}{l}\text { - In your teaching, how do you } \\
\text { encourage unique talents and potential } \\
\text { in every student? } \\
\text { - Do you see students as problems to be } \\
\text { solved or potential to be realized? } \\
\text { - In the classroom, how can you move } \\
\text { from "teacher as expert" to "teacher as } \\
\text { catalyst"? } \\
\text { - In your scholarship, what is the } \\
\text { unique and expansive role you are } \\
\text { called to play? }\end{array}$ & $\begin{array}{l}\text { - What is the unique role that God has } \\
\text { called your college/university to play? } \\
\text { What is your role in helping your } \\
\text { institution achieve this goal? } \\
\text { - Given limited resources, what does } \\
\text { your college/university need to do } \\
\text { really well? What can it do "well } \\
\text { enough"? } \\
\text { - What should never change about your } \\
\text { university? What can change and still } \\
\text { honor the unique place in society that } \\
\text { your institution occupies? }\end{array}$ \\
\hline
\end{tabular}




\begin{tabular}{|c|c|c|}
\hline & In Teaching and Scholarship & In Service to the Institution \\
\hline $\begin{array}{l}\text { Potential as } \\
\text { Practice: } \\
\text { Potential is } \\
\text { dynamic; people } \\
\text { and } \\
\text { organizations } \\
\text { are growing and } \\
\text { developing in } \\
\text { serving God and } \\
\text { others. }\end{array}$ & $\begin{array}{l}\text { - How have you helped students learn } \\
\text { to support and complement each } \\
\text { other's talents and gifts? } \\
\text { - How do you help students give } \\
\text { themselves permission to be works in } \\
\text { progress? } \\
\text { - In your academic discipline, what are } \\
\text { the critical skills your students need to } \\
\text { continually develop and "learn as they } \\
\text { go?" } \\
\text { - In your scholarship, do you try to } \\
\text { perform perfectly or do you allow } \\
\text { yourself to be a person who learns and } \\
\text { develops? When you make a mistake, } \\
\text { how do you respond? }\end{array}$ & $\begin{array}{l}\text { - In a world of scarcity, how are you a } \\
\text { positive voice for deeper } \\
\text { transformation within your academic } \\
\text { community? What gets in the way } \\
\text { when you are not? } \\
\text { - How are you helping your organization } \\
\text { learn and adapt to meet the emerging } \\
\text { challenges facing higher education } \\
\text { today? How are you helping your } \\
\text { institution embrace its unique } \\
\text { strengths? } \\
\text { - What practices can you adopt in your } \\
\text { college/university community that will } \\
\text { model a Christian view of human and } \\
\text { organizational potential? }\end{array}$ \\
\hline $\begin{array}{l}\text { Potential as } \\
\text { Purpose: A } \\
\text { person's value is } \\
\text { not defined } \\
\text { functionally by } \\
\text { what s/he does } \\
\text { or feels, but by } \\
\text { who they are as } \\
\text { a human being } \\
\text { created in God's } \\
\text { image. }\end{array}$ & $\begin{array}{l}\text { - Beyond sharing your expertise, in } \\
\text { what ways do you give students the } \\
\text { skills to translate their Christian faith } \\
\text { into a biblical understanding of } \\
\text { vocation in the world? } \\
\text { - How does God want to use your } \\
\text { teaching and scholarship to redeem a } \\
\text { hurting world? } \\
\text { - How does your teaching and } \\
\text { scholarship reflect God's ongoing care } \\
\text { for and transformation of culture? } \\
\text { - What are you dreaming about doing } \\
\text { within your teaching and scholarship } \\
\text { that can change lives? }\end{array}$ & $\begin{array}{l}\text { - If your college/university did not exist, } \\
\text { would it be created today and for what } \\
\text { purpose? What affirmations would go } \\
\text { into its founding documents and how do } \\
\text { those compare with your institution's } \\
\text { current direction? } \\
\text { - If you had three wishes for your } \\
\text { college/university, what would they be? } \\
\text { Are you giving voice to these wishes } \\
\text { and willing to offer yourself toward } \\
\text { achieving them? } \\
\text { - What is so important on campus or in } \\
\text { your field that it is worth pursuing no } \\
\text { matter the cost? }\end{array}$ \\
\hline $\begin{array}{l}\text { Potential as } \\
\text { Partnership: } \\
\text { People and the } \\
\text { organizations } \\
\text { they serve are } \\
\text { not the first } \\
\text { actors, but are } \\
\text { recipients of } \\
\text { divine grace. } \\
\text { God uses } \\
\text { people's } \\
\text { strengths and } \\
\text { weaknesses, } \\
\text { alike. }\end{array}$ & $\begin{array}{l}\text { - How is God calling you to use both } \\
\text { your strengths and weaknesses in the } \\
\text { classroom? } \\
\text { - To what extent are you creating a safe } \\
\text { space for students to bring their } \\
\text { weaknesses, vulnerabilities, and } \\
\text { questions into the classroom? } \\
\text { - How do you reflect God's ongoing } \\
\text { grace in your teaching and advising? } \\
\text { What are the best ways to } \\
\text { communicate grace for students who } \\
\text { do not perform well? } \\
\text { - In your scholarship, how can you } \\
\text { approach both the scholarly content } \\
\text { and your interactions with colleagues } \\
\text { in a spirit of humility? }\end{array}$ & $\begin{array}{l}\text { - How might God be using the } \\
\text { limitations, weaknesses, and } \\
\text { vulnerabilities of your } \\
\text { college/university or department for } \\
\text { greater purposes? } \\
\text { - How might God be using your } \\
\text { limitations, weaknesses, and } \\
\text { vulnerabilities for service to your } \\
\text { department or institution? } \\
\text { - How comfortable is your } \\
\text { college/university with failure? How } \\
\text { might today's failure be part of God's } \\
\text { bigger plan? }\end{array}$ \\
\hline
\end{tabular}

\section{Place in Higher Education}

Christian educators can draw on the power that a theological understanding of place can offer their teaching, scholarship, and service. Defining potential as place reminds teachers that their role is to see 
students as potential to be realized rather than problems to be solved. Classes should help students identify and draw on the gifts and talents that God has given them. Cynics, optimists, extroverts, and introverts all have important roles to play. The classroom is a place where learning is most effective when students are allowed to develop and share gifts and experiences with one other. Beyond the classroom, focusing on place reminds the instructor that his/her role is to help students find their niche in the body of Christ, in the communities in which they live, in their chosen professions, and in the world at large.

Within scholarship, potential as place gives the Christian academic permission to pursue their academic niche with vigor, confidence, and humility. In God's kingdom, the scholar with the most publications is neither the winner nor the only invited guest at God's table. Instead, every scholar is called to be faithful and fruitful within their unique place in the academy. Furthermore, scholarly work is most effective when it is seen as a catalyst for the gifts and thinking of other scholars and practitioners, not for self-aggrandizement.

At a broader institutional level, Christian colleges and universities are called to play a unique role in God's kingdom. The multiplicity of goals that Christian colleges and universities try to take on is staggering: faith formation, character development, an appreciation of the liberal arts, critical thinking, professional skills, and service to the community, to name but a few. Schools can get caught up in trying to do it all. An alternative approach is to ask, "What is the unique role that God has called this institution to play?" Which goals can we achieve extremely well? Which objectives can we do "well enough"? Christian academic institutions have the potential to partner in creative and interdependent ways that would be difficult for colleges and universities that think in terms of scarcity. For example, as more online options become available, one could imagine multiple Christian colleges specializing in different disciplines and approaches, and sharing faculty and students across an interdependent web-based platform.

\section{Practice in Higher Education}

Practice represents another area where Christian higher education can play an important countercultural role: helping students move beyond knowledge acquisition to shaping practices that will develop their minds, souls, and spirits for a lifetime (Deresiewicz, 2014). One of the fundamental goals of Christian faculty is to do more than simply prepare students to get a good job upon graduation. Rather, they can help students develop the "meta-competencies" to live full and abundant lives at 30, 50, and 70 years of age. These meta-competencies might include the value of continuous learning, working through and overcoming challenges, balancing priorities across multiple life roles, and contributing to their communities. These values represent priorities that any liberal arts college or university might claim. However, Christian higher education can go even further in its commitment to faith and character development. Students can develop discernment practices (e.g., prayer, Sabbath, confession) and cultivate the fruit of their faith (e.g., peace, love, joy). In the classroom, the instructor can move beyond course content by sharing their own faith journey, modeling how they have dealt with struggles, discerned God's direction, and experienced God in their lives.

In scholarship, potential as practice means that Christian scholars recognize that they are works in progress who can draw on God's grace for themselves and others. Their scholarship is a way to unlock God's mysteries and co-participate in God's unfolding creation. Under this paradigm, how they interact with colleagues is just as vital as the scholarly content itself.

Practice has important institution-level implications as well. Institutional integrity is developed as people and organizations practice service, generosity, and good will toward others. Faculty and administrators who see potential as practice are more adaptive, innovative, and willing to experiment with new ways of bringing scholarship and God's grace to students. This is particularly important as Christian colleges and universities face increasing financial challenges. When difficult choices are required about how to balance student tuition, faculty/staff salaries, and capital expenses, administrators and faculty can uphold Christian principles to guide their processes. University participants can be called to consider decisions from multiple stakeholder positions. For example, if faculty/staff salaries are raised, how will this impact aid for economically disadvantaged students? Is it more important to attract the best young 
faculty by paying them higher rates or to ensure that all faculty are paid equally? These are never easy decisions, but Christian principles provide guidance on how members of the body are called to interact with one other in these processes. "In everything do to others as you would have them do to you" (Matt. 7:12, NRSV). "If another member of the church sins, go and point out the fault when the two of you are alone" (Matt. 18:15, NRSV), and forgive your neighbor "not seven times, but seventy-seven times" (Matt. 18:22 NRSV). These are core principles that should define Christian academic communities in the wide array of contexts in which they interact, and are difficult to replicate in organizations that frame decisions within a competitive, scarcity mindset.

In this way, love, humility, and integrity become "nested" concepts that drive personal, corporate, and systemic dimensions (i.e., micro, meso, and macro levels) through shared practices and standards (Treviño et al., 2014). Moreover, the Christian academy becomes a source for modeling these practices in the wide range of communities in which it interacts.

\section{Purpose in Higher Education}

In many organizations purpose is framed as utility and contribution to the bottom line. In an abundance paradigm, organizational mission moves beyond profit as the end goal to consider broader societal contributions (Ghoshal, 2005; Pearce \& David, 1987). Within higher education, the faculty's purpose in the classroom is a sacred responsibility, centered on the call to love God and neighbor. Faculty who approach this role with humility, openness, rigor, and love become part of their students' contextualized learning, making the mutual building of character a living reality (Palmer, 1983). If love for God and for each other is the goal, what is studied and how scholarship is used must contribute to this mission. The pursuit of knowledge is never an end in itself, as it has become in much of higher education today, but rather, part of what it means to develop integrated human beings (Deresiewicz, 2014).

In the Christian academy, purpose plays out in Christian higher education in two important ways. First, faith integration should always be a part of the learning conversation, whether in discovering God's mysteries or being part of God's ongoing creation and culture-making. Moving from a scarcity to an abundance mindset challenges students to ask the bigger questions: How can my discipline positively impact other people and society? How might it be dangerous or misused? What is the ultimate aim of my study? In Christian higher education, Christian scholars are often explicitly rewarded for integrating faith in ways that do not always occur in other institutions (e.g., businesses, government). To embrace purpose, Christian educators must endure in driving vocationally-rich questions in their own teaching and scholarship, as well as asking similarly important questions of their colleagues and institutional decisionmakers.

At the institutional level, Christian higher education is uniquely positioned to develop young adults in ways that are not as possible in weekly one-hour Sunday lessons or less immersive educational contexts. Likewise, state schools are seldom places where issues of faith can be explicitly discussed. Therefore, Christian faculty and administrators are challenged to ensure curricula priorities help students understand the fullness of their identity in Christ, and further develop into fully functioning men and women who both respect and engage the breadth of God's creational and redemptive work in the world.

\section{Partnership with God in Higher Education}

Christian educators see themselves as partners and co-agents of God in their teaching, scholarship, and service. They are reconciled to God in their brokenness and are called to reconcile a broken world. In their teaching, their worth is rooted in God's loving and grace-filled assessment; thus, they are free to acknowledge their weaknesses alongside their strengths. In fact, God is just as likely, if not more likely, to use their weaknesses to affect change in their students, their institutions, and in their broader communities (1 Cor. 1:26-31). Christian educators are called to embrace and practice a posture of

humility in the classroom. Faculty and students alike are not to be valued for their utility, but as God's beloved (Manning, 2002). Within the teaching vocation, this means turning the classroom into a place that is authentic, safe, and where the professor and students can bring their strengths, weaknesses, vulnerabilities, and questions into the light (Manning, 2002). Within scholarship, this means inviting 
Christian academics to approach their research and to interact with colleagues with this same spirit of humility.

At the institutional level, it is essential that curricula, operational decisions, budgets, and priorities spring from the fertile soil of identity in Christ. Manning (2002, p.51) writes: "God's love for you and his choice of you constitute your worth. Accept that and let it become the most important thing in your life." As the Christian university bears God's image in a broken world, it can become a channel of redemptive love, and redemptive love can bring greater vitality to all phases of academic life. No matter the organizational context, a perisseúma mindset prompts a helpful posture of one's personal and organizational dependence upon God, simultaneously unlocking a view that sees possibility for growth, expression, and transformative service to people and communities in need.

\section{CONCLUSION}

The key question for Christian educators, administrators, and staff is how best to restore in others and in our institutions the image of God in all its fullness. How will we work with our students, colleagues, and other stakeholders to cultivate and practice the grace of God? Amidst the intense pressures in Christian higher education, how will we maintain a posture of growth and possibility when so many changes evoke responses of fear and scarcity?

Christian higher education faces a critical inflection point, compelling it to choose between a scarcity and abundance narrative. The theological themes of place, practice, purpose, and partnership offer a new paradigm - one in which human beings are active partners with God in shared service. Will institutions of higher education model a view of human and organizational potential where some are deemed better than others, or will it embody a countercultural spirit of perisseúma? In his commentary on the feeding of the 5,000 , Wesley (2011, commentary on John 6:26) notes that the crowd sought Jesus for their own "temporal advantage." Like them, we too have the tendency to cling to what is visibly available. When we perceive limits and weaknesses, our first response is often to ratchet down our expectations (and interdependencies) of ourselves, others, and our institutions, or secondarily, to compete so we might survive. By failing to recognize the distinct God-given possibility in ourselves, others, and our academic organizations, we forfeit the unique role the Christian academy can and should play in the world- to proclaim a divine story of human value and potential.

\section{REFERENCES}

Bade, M. K., \& Cook S. W. (2008). Functions of Christian prayer in the coping process. Journal for the Scientific Study of Religion, 47(1), 123-133.

Barrick, M. R., \& Mount M. K. (1991). The Big Five personality dimensions and job performance: A meta-analysis. Personnel Psychology, 44(1), 1-26.

Bauer, W. (2000). Perisseúma. In F. Danker (Ed.), A Greek-English Lexicon of the New Testament and Other Early Christian Literature, 3rd ed., (p. 805). Chicago, IL: The University of Chicago Press.

Bertua, C., Anderson, N., \& Salgado J. F. (2005). The predictive validity of cognitive ability tests: A UK meta-analysis. Journal of Occupational and Organizational Psychology, 78(3), 387-409.

Bouchard, T. J., Jr., \& Loehlin, J. C. (2001). Genes, evolution, and personality. Behavior Genetics, 31(3), 243-273.

Brueggemann, W. (1999). The liturgy of abundance, the myth of scarcity. Christian Century, 116(10), 342-347.

Buckingham, M., \& Clifton, D. (2001). Now, discover your strengths. New York, NY: The Free Press.

Cable, M., \& Edwards, J. R. (2004). Complementary and supplementary fit: A theoretical and empirical integration. Journal of Applied Psychology, 89(5), 822-834.

Campion, M. A., Fink, A. A., Ruggeberg, B. J., Carr, L., Phillips, G. M., \& Odman, R. B. (2011). Doing competencies well: Best practices in competency modeling. Personnel Psychology, 64(1), 225262.

196 Journal of Applied Business and Economics Vol. 21(7) 2019 
Castelo, D., \& Stone M. P. (2012). Salvation on display in a holy life. In D. Castelo (Ed.), Holiness as a liberal art (pp. 12-20). Eugene, OR: Pickwick Publications.

Church, A. H., \& Rotolo, C. T. (2013). How are top companies assessing their high-potentials and senior executives? A talent management benchmark study. Consulting Psychology Journal: Practice and Research, 65(3), 199-223.

Code of Federal Regulations. (2011). Part 1607 - Uniform guidelines on employee selection procedures, 1978. Retrieved July 15, 2016, from www.gpo.gov/fdsys/pkg/CFR-2011-title29-vol4/xml/CFR2011-title29-vol4-part1607.xml

Collins, J. C. (2001). Good to great: Why some companies make the leap ... and others don't. New York, NY: Harper Collins Publishers.

Collins, K. J. (2007). The theology of John Wesley: Holy love and the shape of grace. Nashville, TN: Abingdon Press.

Cook, J. I. (1993). Bread. In B. Metzger \& M. Coogan (Eds.), The Oxford companion to the Bible (p. 95). New York, NY: Oxford University Press.

Davis, J. H. F., Schoorman, D., \& Donaldson, L. (1997). Toward a stewardship theory of management. The Academy of Management Review, 22(1), 20-47.

Deresiewicz, W. (2014). Don't send your kids to the Ivy League: The nation's top colleges are turning our kids into zombies. New Republic, July 21. Retrieved November 11, 2014, from www.newrepublic.com/article/118747/ivy-league-schools-are-overrated-send -your-kidselsewhere/

Diddams, M., \& Daniels, D. (2013). Good work with toil: A paradigm for redeemed work. Christian Scholar's Review, 38(1), 61-82.

Duckworth, A. (2016). Grit: The power of passion and perseverance. New York, NY: Scribner.

Dudley, N. M., Orvis, K. A., Lebiecki, J. E., \& Cortina, J. M. (2006) A meta-analytic investigation of conscientiousness in the prediction of job performance: Examining the intercorrelations and the incremental validity of narrow traits. Journal of Applied Psychology, 91(1), 40-57.

Dweck, C. S. (1986). Mindset: The new psychology of success. New York, NY: Balantine Books.

Ericsson, K. A., Charness, N., \& Hoffman R. R. (2006). The Cambridge handbook of expertise and expert performance. Cambridge, UK: Cambridge University Press.

Ericsson, K. A., \& Ward, P. (2007). Capturing the naturally occurring superior performance of experts in the laboratory: Toward a science of expert and exceptional performance. Current Directions in Psychological Science, 16(6), 346-350.

Fredrickson, B. L., Cohn M. A., \& Coffey, K. A. (2008). Open hearts build lives: Positive emotions, induced through loving-kindness meditation, build consequential personal resources. Journal of Personality and Social Psychology, 95(5), 1045-1062.

Friedman, M. (1970). The social responsibility of business is to increase its profits. The New York Times, September 13. Retrieved September 7, 2015, from www.colorado.edu/studentgroups/libertarians/issues/friedman-soc-resp-business.html

Gates, B. (2008). Creative capitalist. In M. Kinsley (Ed.), Creative capitalism: A conversation with Bill Gates, Warren Buffett and other economic leaders (pp. 7-19). New York, NY: Simon \& Schuster.

Ghoshal, S. (2005). Bad management theories are destroying good management practices. Academy of Management Learning and Education, 4(1), 75-91.

Glanzer, P. L. (2014). Dispersing the light: The status of Christian higher education around the globe. Christian Scholar's Review, 42(4), 321-44.

Grant, A. M., \& Gino, F. (2010). A little thanks goes a long way: Explaining why gratitude expressions motivate prosocial behavior. Journal of Personality and Social Psychology, 98(6), 946-955.

Guinness, O. (1998). The call: Finding and fulfilling the central purpose of your life. Nashville, TN: Word Publishing.

Guthrie, D. (1994). John. In G. Wenham, J. Motyer, \& D. Carson (Eds.), New Bible commentary, 21st century edition (pp. 1021-1065). Downers Grove, IL: InterVarsity Press. 
Hertel, G. (2011). Synergetic effects in working teams. Journal of Managerial Psychology, 26(3), 176184.

Hill, P. C., \& Pargament, K. I. (2008). Advances in the conceptualization and measurement of religion and spirituality: Implications for physical and mental health research. Psychology of Religion and Spirituality, 1(1), 3-17.

Hurst, A. (2014). The purpose economy: How your desire for impact, personal growth, and community is changing the world. Boise, ID: Elevate.

Kristoff-Brown, A. L., Zimmerman R. D., \& Johnson E. C. (2005). Consequences of individual's fit at work: A meta-analysis of person-job, person-organization, person-group, and person-supervisor fit. Personnel Psychology, 58(2), 281-342.

Li, Y., Baldassi, M., \& Johnson, E. (2013). Complementary cognitive capabilities, economic decision making, and aging. Psychology and Aging, 28(3), 595-613.

Mackey, J., \& Sisodia, R. (2013). Conscious capitalism: Liberating the heroic spirit of capitalism. Boston, MA: Harvard Business School Publishing Corporation.

Maddox, R. L. (1994). Responsible grace: John Wesley's practical theology. Nashville, TN: Abingdon Press.

Manning, B. (2002). Abba's child. Colorado Springs, CO: NavPress.

McCullough, M. E., \& Willoughby, B. L. B. (2009). Religion, self-regulation, and self-control: Associations, explanations, and implications. Psychological Bulletin, 135(1), 69-93.

Moltmann, J. (1967). Theology of hope. New York, NY: Harper \& Row.

Moltmann, J. (2004). In the end, the beginning: A life of hope. Minneapolis, MN: Fortress Press.

Ng, T. W. H., \& Feldman, D. C. (2013) How do within-person changes due to aging affect job performance? Journal of Vocational Behavior, 83(3), 500-513.

Ohland, M., Loughry, M. L., Woehr, D. J., Bullard, L. G., Finelli, C. J., Layton, R. A., ...Schmucker, D. G. (2012). The comprehensive assessment of team member effectiveness: Development of a behaviorally anchored rating scale for self-and peer evaluation. Academy of Management Learning \& Education, 11(4), 609-630.

Orwell, G. (1946). Animal Farm. New York, NY: Harcourt Brace.

Palmer, P. (1983). To know as we are known: A spirituality of education. San Francisco, CA: Harper \& Row.

Paloutzian, R. F., Richardson, J. T., \& Rambo L. R. (1999). Religious conversion and personality change. Journal of Personality, 67(6), 1047-1079.

Pargament, K. I. (2008) The sacred character of community life. American Journal of Community Psychology, 41(1-2), 22-34.

Pargament, K. I., Koenig, H. G., Tarakeshwar, N., \& Hahn, J. (2001). Religious struggle as a predictor of mortality among medically ill elderly patients: A 2-Year longitudinal study. Archives of Internal Medicine, 161(15), 1881-1885.

Park, C. L. (2012) Religious and spiritual aspects of meaning in the context of work life. In P. Hill \& B. Dik (Eds.), Psychology of religion and workplace spirituality (pp. 25-42). Charlotte, NC: Information Age Publishing.

Pearce, J. A., \& David, F. (1987). Corporate mission statements: The bottom line. The Academy of Management Executive, 1(2), 109-115.

Smith, R., \& Spinath F. M. (2004). Intelligence: Genetics, genes, and genomics. Journal of Personality and Social Psychology, 86(1), 112-129.

Porter, M. E. (1979). How competitive forces shape strategy. Harvard Business Review, 57(2), 21-38.

Porter, M. E., \& Kramer M. R. (2011). Creating shared value. Harvard Business Review, 89(1/2), 62-77.

Reed, S. A. (2000). Bread. In D. Freedman, A. Myers, and A. Beck (Eds.), Eerdmans dictionary of the Bible (p. 199). Grand Rapids, MI: William B. Eerdmans Publishing Company.

Roberts, B. W., \& DelVecchio, W. F. (2000). The rank-order consistency of personality traits from childhood to old age: A quantitative review of longitudinal studies. Psychological Bulletin, 126(1), 3-25.

198 Journal of Applied Business and Economics Vol. 21(7) 2019 
Roberts, B. W., Walton K. E., \& Viechtbauer, W. (2006). Patterns of mean-level change in personality traits across the life course: A meta-analysis of longitudinal studies. Psychological Bulletin, 132(1), 1-25.

Ryan, A. M., \& Tippins, N. T. (2004). Attracting and selecting: What psychological research tells us. Human Resource Management, 43(4), 305-318.

Salas, E., Shuffler, M. L., \& Thayer A. L. (2014). Understanding and improving teamwork in organizations: A scientifically based practical guide. Human Resource Management, 54(4), 599622.

Salgado, J. F., Anderson, N., Moscoso, S., Bertua, C., de Fruyt, F., \& Rolland, J. P. (2003) A metaanalytic study of general mental ability validity for different occupations in the European community. Journal of Applied Psychology, 88(6), 1068-1081.

Schmidt, F. L., \& Hunter, J. (2004). General mental ability in the world of work: Occupational attainment and job performance. Journal of Personality and Social Psychology, 86(1), 162-173.

Schneider, B. (1987). The people make the place. Personnel Psychology, 40(3), 437-453.

Schuerger, J. M., \& Witt, A. C. (1989). Temporal stability of individually tested intelligence. Journal of Clinical Psychology, 45(2), 294-302.

Schuurmann, D. J. (2004). Vocation: Discerning our callings in life. Grand Rapids, MI: Eerdmans Publishing Company.

Scott, J. M. C. (2003) John. In J. Dunn \& J. Rogerson (Eds.), Eerdmans commentary on the Bible (pp. 1161-1212). Grand Rapids, MI: William B. Eerdmans Publishing Company.

Silzer, R., \& Church A. H. (2009). The pearls and perils of identifying potential. Industrial and Organizational Psychology: Perspectives on Science and Practice, 2(4), 377-412.

Smith, E. E. (2013). There's more to life than being happy. The Atlantic, January 9. Retrieved November 11, 2014, from www.theatlantic.com/health/archive/2013/01/theres-more-to-life-than-beinghappy/266805/

Spreitzer, G., \& Cameron, K. (2012) Applying a POS lens to bring out the best in organizations. Organizational Dynamics, 41(2), 85-88.

Stein, R. H. (1989). Bread. In M. Powell (Ed.), The HarperCollins Bible dictionary (pp. 105). New York, NY: HarperOne.

Strong, D. M. (2012). A heritage of holiness: Themes of sanctification in the Christian tradition. In D. Castelo (Ed.), Holiness as a liberal art (pp. 61-70). Eugene, OR: Pickwick Publications.

Thayer, J. H. (1889). Greek-English lexicon of the New Testament. New York, NY: American Book Company. Retrieved September 7, 2015, from www.christianresearcher.com/uploads/1/6/2/9/16298120/01 greekenglishlexicongrimmthayer.pdf

Treviño, L. K., den Nieuwenboer, N. A., \& Kish-Gephart, J. J. (2014). (Un)ethical behavior in organizations. Annual Review of Psychology, 65, 635-660.

Uhl-Bien, M., Marion, R., \& McKelvey, B. (2007). Complexity leadership theory: Shifting leadership from the industrial age to the knowledge era. The Leadership Quarterly, 18(4), 298-318.

Van Duzer, J. (2010). Why business matters to God (And what still needs to be fixed). Downers Grove, IL: InterVarsity Press.

Van Duzer, J., Franz R. S., Karns G. L., Wong, K. L., \& Daniels, D. (2007). It's not your business: A Christian reflection on stewardship and business. Journal of Management, Spirituality and Religion, 4(1), 99-122.

Vawter, B. (1968). The gospel according to John. In R. Brown, J. Fitzmyer, \& R. Murphy (Eds.), The Jerome biblical commentary, Vol. 2 (p. 414-466). Englewood Cliffs, NJ: Prentice-Hall.

Wesley, J. (1872). Sermon 51. In T. Jackson T (Ed.), The Sermons of John Wesley. Retrieved July 25, 2016, from www.wesley.nnu.edu/john-wesley/the-sermons-of-john-wesley-1872-edition/

Wesley, J. (2011) Notes on the gospel according to St John. In The Wesley Center Online. Retrieved July 25, 2016, from www.wesley.nnu.edu/john-wesley/john-wesleys-notes-on-the-bible/notes-on-thegospel-according-to-st-john/ 
Wong, K., Baker, B., \& Franz, R. (2015). Reimagining business education as formation. Christian Scholar's Review, 45(1), 5-30.

Worthington, E. L. (2008) Empirical research on forgiveness with Christians: What have we learned? Journal of Psychology and Christianity, 27(4), 368-370.

Wright, N. T. (2008). Surprised by hope: Rethinking heaven, the resurrection, and the mission of the church. New York, NY: HarperOne.

Wrzesniewski, A., \& Dutton J. E. (2001). Crafting a job: Revisioning employees as active crafters of their work. Academy of Management Review, 26(2), 179-201.

Yost, P. R., \& Chang, G. (2009) Everyone is equal, but some are more equal than others. Industrial and Organizational Psychology: Perspectives on Science and Practice, 2(4), 442-445. 